\title{
Identification of 15 novel polymorphic microsatellite loci in pearl oyster (Pinctada fucata)
}

\author{
S.G. Fan ${ }^{1}$, J.X. Wang', ${ }^{1,2}$ D.L. Zhang ${ }^{3}$, Y.H. Guo ${ }^{1}$ and D.H. Yu ${ }^{1}$ \\ ${ }^{1}$ Key Laboratory of South China Sea Fishery Resources Exploitation \& \\ Utilization, Ministry of Agriculture, South China Sea Resource Exploitation \\ and Protection Collaborative Innovation Center, South China Sea Fisheries \\ Research Institute, Chinese Academy of Fishery Sciences, Guangzhou, China \\ ${ }^{2}$ College of Fisheries and Life Science, Shanghai Ocean University, Shanghai, \\ China \\ ${ }^{3}$ Fisheries College, Jimei University, Xiamen, China \\ Corresponding author: D.H. Yu \\ E-mail: 18602058697@163.com
}

Genet. Mol. Res. 15 (4): gmr.15048655

Received March 24, 2016

Accepted July 5, 2016

Published October 5, 2016

DOI http://dx.doi.org/10.4238/gmr.15048655

Copyright (C) 2016 The Authors. This is an open-access article distributed under the terms of the Creative Commons Attribution ShareAlike (CC BY-SA) 4.0 License.

\begin{abstract}
The pearl oyster Pinctada fucata is a commercially important marine shellfish. As a result, genetic improvement and selective-breeding program have been conducted for this species. Polymorphic microsatellites are effective molecular markers to investigate molecular marker-assisted selection and genetic variance. In this study, microsatellite DNAs were screened and characterized based on the partial genome sequence of $P$. fucata. We identified 111 microsatellite DNA motifs through mining the published draft genome sequence of $P$. fucata. Forty-two loci were screened with $8 P$. fucata individuals, and 15 were found to be polymorphic and were therefore
\end{abstract}


further evaluated using 40 wild individuals from the Daya Bay, Shenzhen City, Guangdong Province, China. The number of alleles per locus ranged from 3 to 8, with an average of 5.2667 for the 15 polymorphic loci. Observed and expected heterozygosities ranged from 0.1154 to 0.6216 ( 0.3321 on average) and 0.4950 to 0.8491 ( 0.6768 on average), respectively. Of the 15 polymorphic loci, 12 loci deviated from Hardy-Weinberg equilibrium after Bonferroni correction $(\mathrm{P}<$ 0.0033 ). Polymorphism information content ranged from 0.44 to 0.83 with a mean value of 0.63 . The results suggest that the markers isolated in this study can be used for research on molecular marker-assisted selection and genetic variance of $P$. fucata.

Key words: Pinctada fucata; Polymorphism; Microsatellite; Genetic diversity

\section{INTRODUCTION}

The pearl oyster Pinctada fucata (Gould, 1850) is a commercially important marine shellfish cultured for producing marine pearls, mainly in China and Japan (Yu and Chu, 2006). It is common in tropical and subtropical oceans and seas in the Pacific and Indian regions. In China, the first successful artificial propagation of this species was conducted in Guangxi Province in 1965, which allowed the pearl culture practice to subsequently expand rapidly to the neighboring Guangdong and Hainan Provinces (Meng et al., 1996). The pearls produced by these animals are referred to as "South Pearl", and they account for over $90 \%$ of the total marine pearls produced in China. Yet, because of overfishing, coastal water pollution, and inbreeding depression by years of artificial propagation without recording of their background, some traits of $P$. fucata appear to have degenerated, which hampers the development of the pearl industry (Niu et al., 2015). Thus, genetic improvement and selective breeding of elite varieties should be conducted to prevent the growth traits of the animal from degenerating to maintain pearl quality (Wada and Jerry, 2008).

Because of their co-dominance, high polymorphism, and genome-wide abundance, microsatellites (simple sequence repeats, SSRs) are effective molecular markers used in molecular marker-assisted selection and to maintain genetic variance in shellfish (Li et al., 2003; Sato et al., 2005; Evans et al., 2006; Andrea et al., 2014; Silva Neta et al., 2015). Although some polymorphic microsatellite loci have been isolated for P. fucata (Kuang et al., 2009; Fan et al., 2014), more SSRs are needed for genetic research. Developing SSRs from published data, such as ESTs and genome sequences, is low-cost and highly effective (Guo et al., 2013; Andrea et al., 2014; Tan et al., 2014). Genomic SSRs are more likely to be polymorphic than EST-SSRs (Kong et al., 2014). The publication of the draft genome sequence of $P$. fucata (Takeuchi et al., 2012) has made it possible to mine SSR motifs from its genomic sequence. In this study, 111 microsatellite loci were screened from part of the genomic data of P. fucata, and 15 polymorphic microsatellite loci were identified that would be useful in molecular markerassisted selection and the maintenance of genetic variance in $P$. fucata.

\section{MATERIAL AND METHODS}

Wild adult individuals $(\mathrm{N}=40)$ of $P$. fucata (shell length: $4-5 \mathrm{~cm}$ ) were collected

Genetics and Molecular Research 15 (4): gmr.15048655 
randomly from Daya Bay, Shenzhen $\left(22.55^{\circ} \mathrm{S}, 114.52^{\circ} \mathrm{E}\right)$ and transported to our laboratory in Guangzhou. Adductor muscle were dissected and preserved in $95 \%$ ethanol and stored at $-20^{\circ} \mathrm{C}$. DNA from the adductor muscle tissue was extracted immediately using the TIANamp Marine Animals DNA Kit (Tiangen Products, Beijing, China) according to the manufacturer specification. Partial genomic sequences of $P$. fucata, including scaffold1.1, scaffold2.1, and scaffold3.1, were downloaded from the P. fucata genome platform (http://marinegenomics. oist.jp/pinctada fucata). Microsatellite sequence motifs were discovered with SSR Hunter 1.3 (Li and Wan, 2005) and di-, tri-, tetra-, penta-, and hexanucleotide motifs were identified with a minimum of six, five, four, four, and four repeats, respectively. SSR-containing sequences with sufficient flanking sequences (no less than $150 \mathrm{bp}$ ) were selected for characterization. For selected microsatellite loci, 42 primer pairs were designed using Primer Premier 5.0 (Premier Biosoft International, USA) (Table 1).

Forty-two primers were synthesized and verified by PCR in eight $P$. fucata individuals. PCR amplification was performed in 20- $\mu \mathrm{L}$ reactions containing 30-50 ng genomic DNA, 1 U rTaq polymerase (Takara, Japan), 1X PCR buffer, $1.5 \mathrm{mM} \mathrm{MgCl}_{2}, 0.2 \mathrm{mM}$ dNTPs, and 0.2 $\mu \mathrm{M}$ each primer. The amplification conditions were as follows: initial denaturation at $95^{\circ} \mathrm{C}$ for $5 \mathrm{~min}$, followed by 30 cycles of $94^{\circ} \mathrm{C}$ for $30 \mathrm{~s}$, a primer-specific annealing temperature for 30 $\mathrm{s}$, and $72^{\circ} \mathrm{C}$ for $1 \mathrm{~min}$, with a final extension at $72^{\circ} \mathrm{C}$ for $7 \mathrm{~min}$. The Eppendorf MasterCycler ${ }^{\circledR}$ gradient S (Hamburg, Germany) was utilized for PCR. PCR products were examined with electrophoresis on an $8 \%$ non-denaturing polyacrylamide gel (200 V, $150 \mathrm{~min}$ ) and visualized with silver staining. Successfully amplified primers were further characterized with 40 individuals of $P$. fucata. PCR amplification and profile were the same as above.

Genetic variation in terms of number of alleles $\left(N_{\mathrm{A}}\right)$, number of effective alleles, observed $\left(H_{\mathrm{O}}\right)$ and expected $\left(H_{\mathrm{E}}\right)$ heterozygosities, and the probability of a deviation from Hardy-Weinberg equilibrium (HWE) were calculated using Popgene 1.32 (Yeh and Boule, 2000). Polymorphism information content (PIC) was calculated using the PIC Calc online software (Nagy et al., 2012).

\section{RESULTS AND DISCUSSION}

SSR locus screening from published whole-genome data was low-cost, time-saving, and highly efficient. Nearly 1,162,212 nucleotides were downloaded from the $P$. fucata genome platform, and 49,43, and 19 SSR motifs were found in scaffold1.1, scaffold2.1, and scaffold3.1, respectively. Among others, primer pairs of 42 motifs were designed and verified in 8 individuals of $P$. fucata. As a result, 13 failed to amplify any PCR products and 29 produced clear and specific bands, of which 15 showed to be polymorphic and were deposited in GenBank (accession Nos. KT714056-KT714070) (Table 1).

The 15 polymorphic loci were further characterized using 40 wild $P$. fucata individuals from the Daya Bay, Shenzhen (Guangdong Province, China). As shown in Table 2, the $N_{\mathrm{A}}$ per locus ranged from 3 to 8 with an average of 5.2667. $H_{\mathrm{O}}$ and $H_{\mathrm{E}}$ varied from 0.1154 to 0.6216 ( 0.3321 on average) and 0.4950 to 0.8491 ( 0.6768 on average), respectively. Among the 15 polymorphic loci, 12 loci deviated from HWE after Bonferroni correction, possibly because of a heterozygote deficit (Kuang et al., 2009) or the occurrence of a non-amplifying null allele (Qiu et al., 2013). The PIC ranged from 0.44 to 0.83 with an average of 0.63 . The informativeness value for these genomic SSR markers (0.63) was higher than the genomic SSR marker value (0.37) for P. fucata reported by Kuang et al. (2009).

Genetics and Molecular Research 15 (4): gmr.15048655 
Table 1. Characteristics of 15 microsatellite loci in Pinctada fucata.

\begin{tabular}{|c|c|c|c|c|c|}
\hline Locus & Primer sequences $\left(5^{\prime}-3^{\prime}\right)$ & Repeat & $\mathrm{Ta}\left({ }^{\circ} \mathrm{C}\right)$ & Size (bp) & GenBank accession No. \\
\hline \multirow[t]{2}{*}{ scd1.1-1 } & F:CCGGTGTCACATTAAATTAAGAGC & $(\mathrm{GTCC})_{4}$ & 55 & $176-250$ & KT714056 \\
\hline & R:TAACAGACTAAACACTACATGGCCG & & & & \\
\hline \multirow[t]{2}{*}{ scd1.1-3 } & F:TAGTGGAAAGCCCAGAGGTAAT & $(\mathrm{TCTG})_{7}$ & 55 & $242-250$ & KT714057 \\
\hline & R:AGAGGGGATAGACCTCAGACAA & & & & \\
\hline \multirow[t]{2}{*}{ scd1.1-4 } & F:GGGTGGGAGACAGAATAGCATA & $(\text { TAGA })_{4}$ & 57 & $360-400$ & KT714058 \\
\hline & R:TAATTCACATAGGTCGCCATCA & & & & \\
\hline \multirow[t]{2}{*}{$\operatorname{scd} 1.1-12$} & F:TCAGGCAATATCCATATCCACC & $(\mathrm{AT})_{9}$ & 55 & $180-250$ & KT714059 \\
\hline & R:TGGAGTTCAGTCCCCTTCTTGT & & & & \\
\hline \multirow[t]{2}{*}{$\operatorname{scd} 1.1-15$} & F:TATCGGAAGTTTTGCGAGACC & $(\mathrm{AAC})_{12}$ & 53 & $170-200$ & KT714060 \\
\hline & R:ATGGCAAGTGTTCCTCAAAGTG & & & & \\
\hline \multirow[t]{2}{*}{ scd2.1-10 } & F:GTATCTGAAAGAAACGATCTG & $(\mathrm{GAT})_{14}$ & 49 & $120-200$ & KT714061 \\
\hline & R:CACTAGAATAAATGTGGAAGC & & & & \\
\hline \multirow[t]{2}{*}{$\operatorname{scd} 2.1-15$} & F:TGAGATGGATTTTCAGACGC & $\left(\mathrm{AT}_{7}\right.$ & 55 & $100-120$ & KT714062 \\
\hline & R:CCTGGAAGAGTTTGTAGTAAACACG & & & & \\
\hline \multirow[t]{2}{*}{$\operatorname{scd} 2.1-17$} & F:TTTATCGGGCTTATCGCTTTC & $(\mathrm{TGTT})_{7}$ & 55 & $200-230$ & KT714063 \\
\hline & R:CAACCTGGAGTATCCTGAAAGAAC & & & & \\
\hline \multirow[t]{2}{*}{ scd3.1-1 } & F:TCGCACTATTTCAAGACTAT & $(\mathrm{AT})_{7}$ & 49 & $190-220$ & KT714064 \\
\hline & R:TTCATACCTGATTAAGCATC & & & & \\
\hline \multirow[t]{2}{*}{ scd3.1-2 } & F:CGATGAAGACGGCATACCTG & $(\mathrm{TA})_{6}$ & 55 & $280-300$ & KT714065 \\
\hline & R:TCCCCTCCTGTGACCCATTA & & & & \\
\hline \multirow[t]{2}{*}{$\operatorname{scd} 3.1-3$} & F:TCTGTACCTCCACATGACTG & $(\mathrm{ATGA})_{8}$ & 53 & $200-250$ & KT714066 \\
\hline & R:CAGCCATTTGGAGACATAGA & & & & \\
\hline \multirow[t]{2}{*}{$\operatorname{scd} 3.1-6$} & F:ATCAAGGGGCACTTTGGTTC & $(\mathrm{AGG})_{5}$ & 53 & $300-330$ & KT714067 \\
\hline & R:TCAAATGTTTACGAAGTAGGGG & & & & \\
\hline \multirow[t]{2}{*}{ scd3.1-11 } & F:TTCATTGGGTGTTGAGGCTTAT & $(\mathrm{GACA})_{4}$ & 55 & $260-400$ & KT714068 \\
\hline & R:ATTCGGAACAGCGGAAGTCG & & & & \\
\hline \multirow[t]{2}{*}{ scd3.1-12 } & F:TGCCAAACTTGTGCTCCTTC & $(\mathrm{CAA})_{6}$ & 55 & $150-200$ & KT714069 \\
\hline & R:AGATTGCGTCGTCGGAACAT & & & & \\
\hline \multirow[t]{2}{*}{ scd3.1-14 } & F:TAATGTCTCAGTGCTGTTCT & $(\mathrm{TA})_{6}$ & 50 & $320-390$ & KT714070 \\
\hline & R:GTGCCATTGGATACCAGT & & & & \\
\hline
\end{tabular}

Ta: annealing temperature.

Table 2. Result of screening 15 polymorphic microsatellite loci with 40 individuals of Pinctada fucata.

\begin{tabular}{|c|c|c|c|c|c|}
\hline Locus & $N_{\mathrm{A}}$ & $N_{\mathrm{E}}$ & $H_{\mathrm{O}}$ & $H_{\mathrm{E}}$ & PIC \\
\hline $\operatorname{scd} 1.1-1^{\mathrm{a}}$ & 6 & 4.8809 & 0.1154 & 0.7951 & 0.77 \\
\hline $\operatorname{scd} 1.1-3^{\mathrm{a}}$ & 7 & 4.8855 & 0.6000 & 0.7953 & 0.76 \\
\hline $\operatorname{scd} 1.1-4^{\mathrm{a}}$ & 5 & 2.5423 & 0.2895 & 0.6066 & 0.57 \\
\hline scd1.1-12 & 6 & 3.8216 & 0.5641 & 0.7383 & 0.70 \\
\hline scd1.1-15 & 6 & 4.4520 & 0.6216 & 0.7754 & 0.74 \\
\hline $\operatorname{scd} 2.1-10^{\mathrm{a}}$ & 8 & 5.3963 & 0.5000 & 0.8147 & 0.79 \\
\hline $\operatorname{scd} 2.1-15^{\mathrm{a}}$ & 4 & 2.8089 & 0.2308 & 0.6440 & 0.58 \\
\hline $\operatorname{scd} 2.1-17^{\mathrm{a}}$ & 4 & 2.1744 & 0.2051 & 0.5401 & 0.48 \\
\hline $\operatorname{scd} 3.1-1^{\mathrm{a}}$ & 3 & 2.3038 & 0.1500 & 0.5659 & 0.50 \\
\hline $\operatorname{scd} 3.1-2^{a}$ & 3 & 1.9802 & 0.0667 & 0.4950 & 0.44 \\
\hline $\operatorname{scd} 3.1-3^{\mathrm{a}}$ & 8 & 6.6253 & 0.2500 & 0.8491 & 0.83 \\
\hline $\operatorname{scd} 3.1-6^{\mathrm{a}}$ & 4 & 3.0124 & 0.1515 & 0.6680 & 0.61 \\
\hline $\operatorname{scd} 3.1-11$ & 6 & 2.4336 & 0.4872 & 0.5891 & 0.54 \\
\hline $\operatorname{scd} 3.1-12^{\mathrm{a}}$ & 4 & 2.1462 & 0.2500 & 0.5341 & 0.47 \\
\hline $\operatorname{scd} 3.1-14^{\mathrm{a}}$ & 5 & 3.8610 & 0.5000 & 0.7410 & 0.70 \\
\hline Mean & 5.2667 & 3.5550 & 0.3321 & 0.6768 & 0.632 \\
\hline
\end{tabular}

$N_{\text {}}$, number of alleles; $N_{\mathrm{E}}$, effective number of alleles; $H_{\mathrm{O}}$, observed heterozygosity; $H_{\mathrm{E}}$, expected heterozygosity;

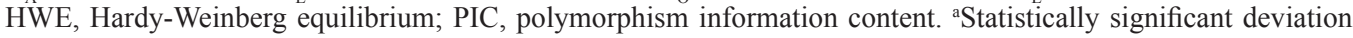
from HWE after Bonferroni correction $(\mathrm{P}<0.0033)$.

Genetics and Molecular Research 15 (4): gmr.15048655 
In conclusion, 15 polymorphic microsatellite loci were screened and identified from the published genomic sequence of $P$. fucata. These microsatellites were effective for investigating the population genetics of $P$. fucata. They would facilitate research on molecular marker-assisted selection and genetic variance in $P$. fucata.

\section{Conflicts of interest}

The authors declare no conflict of interest.

\section{ACKNOWLEDGMENTS}

Research supported by the earmarked fund for China Agriculture Research System (Grant \#CARS-48), the National Natural Science Foundation of China (\#31372525), the PhD Start-up Fund of Natural Science Foundation of Guangdong Province (\#2014A030310237), the Natural Science Foundation Program of Hainan Province (\#20154180), and the Basic Scientific Research Fund for the Central Institutes of Public Welfare (South China Sea Fisheries Research Institute, \#2014TS08).

\section{REFERENCES}

Andrea AE, Natalia VA, Rodolfo F, Fabiola LC, et al. (2014). Development of novel polymorphic EST-SSR markers in Californian abalone Haliotis rufescens and genetic analysis in wild and hatchery-bred populations. Aquatic Res. 45: 1942-1952. http://dx.doi.org/10.1111/are.12141

Evans BS, Knauer J, Taylor JU and Gerry DR (2006). Development and characterization of six new microsatellite markers for the silver- or gold-lipped pear oyster, Pinctada maxima (Pteriidae). Mol. Ecol. Notes 6: 835-837. http://dx.doi. org $/ 10.1111 / \mathrm{j} .1471-8286.2006 .01362 . \mathrm{x}$

Fan S, Wang J, Huang G, Liu B, et al. (2014). Identification of twenty novel polymorphic microsatellite DNA markers from transcripts of the pearl oyster Pinctada fucata using next-generation sequencing approach. J. Genet. 93: e82-e85.

Guo WJ, Yu XM and Tong JG (2013). Development of 134 novel polynucleotide-repeat microsatellite markers in silver carp (Hypophthalmichthys molitrix). Conserv. Genet. Resour. 5: 525-528. http://dx.doi.org/10.1007/s12686-012$\underline{9843-\mathrm{y}}$

Kong LF, Bai J and Li Q (2014). Comparative assessment of genomic SSR, EST-SSR and EST-SNP markers for evaluation of the genetic diversity of wild and cultured Pacific oyster, Crassostrea gigas Thunberg. Aquaculture 420-421: S85-S91. http://dx.doi.org/10.1016/j.aquaculture.2013.05.037

Kuang YY, Tong GX, Yan XC and Sun XW (2009). Rapid isolation and characterization of microsatellites from the genome of pearl oyster (Pinctada martensii Dunker). Conserv. Genet. 10: 1463-1467. http://dx.doi.org/10.1007/ s10592-008-9761-4

Li G, Hubert S, Bucklin K, Ribes V, et al. (2003). Characterization of 79 microsatellite DNA markers in the Pacific oyster Crassostrea gigas. Mol. Ecol. Notes 3: 228-232. http://dx.doi.org/10.1046/j.1471-8286.2003.00406.x

Li Q and Wan JM (2005). SSRHunter: development of a local searching software for SSR sites. Yi Chuan 27: 808-810.

Meng Z, Li Y and Xing K (1996). Theory and techniques on pearl culture. Science Press, Beijing (in Chinese).

Nagy S, Poczai P, Cernák I, Gorji AM, et al. (2012). PICcalc: an online program to calculate polymorphic information content for molecular genetic studies. Biochem. Genet. 50: 670-672. http://dx.doi.org/10.1007/s10528-012-9509-1

Niu ZK, Liu BS, Zhang DL, Tan CG, et al. (2015). Comparative analysis of growth traits and shell-closing strength among hybrid populations from three geographical groups of pearl oyster (Pinctada fucata). S. China Fish. Sci. 11: 26-32.

Qiu Y, Huang XZ, Lu H, Shi YH, et al. (2013). Development of EST-derived microsatellite markers in the pearl oyster Pinctada martensii (Dunker) for genetic resource monitoring. Conserv. Genet. Resour. 5: 401-403. http://dx.doi. org/10.1007/s12686-012-9813-4

Sato M, Kawamata K, Zaslavskaya N, Nakamura A, et al. (2005). Development of microsatellite markers for Japanese scallop (Mizuhopecten yessoensis) and their application to a population genetic study. Mar. Biotechnol. (NY) 7: 713728. http://dx.doi.org/10.1007/s10126-004-0127-8

Genetics and Molecular Research 15 (4): gmr.15048655 
Silva Neta MT, Maciel BM, Lopes AT, Marques EL, et al. (2015). Microbiological quality and bacterial diversity of the tropical oyster Crassostrea rhizophorae in a monitored farming system and from natural stocks. Genet. Mol. Res. 14: 15754-15768. http://dx.doi.org/10.4238/2015.December.1.27

Takeuchi T, Kawashima T, Koyanagi R, Gyoja F, et al. (2012). Draft genome of the pearl oyster Pinctada fucata: a platform for understanding bivalve biology. DNA Res. 19: 117-130. http://dx.doi.org/10.1093/dnares/dss005

Tan M, Wu K, Wang L, Yan MF, et al. (2014). Developing and characterising Ricinus communis SSR markers by data mining of whole-genome sequences. Mol. Breed. 34: 893-904. http://dx.doi.org/10.1007/s11032-014-0083-6

Wada KT and Jerry DR (2008). Population genetics and stock improvement. In: The pearl oyster (Southgate PC and Lucas JS, eds.). Elsevier, Amsterdam, 437-471.

Yeh C and Boule T (2000). POPGENE-1.32: A free program for the analysis of genetic variation among and within populations using co-dominant and dominant markers. Department of Renewable Resources at the University of Alberta, Canada.

$\mathrm{Yu}$ DH and Chu KH (2006). Genetic variation in wild and cultured populations of the pearl oyster Pinctata fucuta from southern China. Aquaculture 258: 220-227. http://dx.doi.org/10.1016/j.aquaculture.2006.03.024

Genetics and Molecular Research 15 (4): gmr.15048655 